\title{
PREFERENSI LOKASI INDUSTRI MENENGAH DI WILAYAH KABUPATEN MALANG
}

\author{
Raffli Noor, Agam Marsoyo, R. Widodo Dwi Pramono \\ Kementerian PPN/Bappenas \\ Jalan Taman Suropati No. 2 Menteng, Jakarta Pusat 10310 - Telp (021) 3927412 \\ raffli.noor@gmail.com
}

\begin{abstract}
ABSTRAK
Lokasi merupakan salah satu faktor penting bagi kegiatan ekonomi termasuk kegiatan industri, sehingga penentuan lokasi industri harus mempertimbangkan faktor-faktor lokasi yang mempengaruhinya. Tujuan studi ini adalah mengetahui pola distribusi spasial industri menengah dan mengukur pengaruh faktor geografis (bahan baku, tenaga kerja, pasar, transportasi, dan utilitas) terhadap preferensi lokasi industri menengah di Kabupaten Malang. Metode yang digunakan pada penelitian ini adalah metode deduktif dengan analisa kuantitatif. Untuk mengetahui pola distribusi spasial industri menengah digunakan analisis Indeks Moran's I sedangkan untuk mengukur pengaruh faktor geografis terhadap preferensi lokasi industri menengah digunakan analisis statistik diskriminan. Hasil analisis menggunakan Indeks Moran's I diketahui pola distribusi spasial industri menengah adalah menyebar secara acak (random). Faktor yang mempengaruhi preferensi lokasi industri menengah dekat dengan jalan atau jauh dari jalan berdasarkan hasil analisis statistik diskriminan adalah: (i) jarak antara sumber bahan baku dengan lokasi industri; (ii) jarak asal tenaga kerja dengan lokasi industri; (iii) jarak lokasi industri dengan utilitas; (iv) jarak pasar dengan lokasi industri; dan (v) jarak lokasi industri dengan rumah pemilik industri. Faktor yang paling berpengaruh adalah jarak lokasi industri dengan rumah pemilik industri dan jarak lokasi industri dengan utilitas karena memiliki nilai koefisien fungsi yang paling besar.
\end{abstract}

Kata Kunci : preferensi lokasi, industri menengah, faktor geografis.

\begin{abstract}
Location is one of the important factors for economic activity including industrial activities. Therefore, the determination of industrial site must consider the factors that influence the location. The purpose of this study is to know the spatial distribution pattern of medium industries and to measure the influence of geographical factors (raw materials, human capital, market, transportation, and utility) to medium industries location preference in Malang Regency. The method used in this research is deductive method with quantitative analysis. To know the pattern of spatial distribution of medium industries, this research used Moran's I Index analysis, while to measure the influence of geographical factor to medium industries location preference, it used discriminant statistical analysis. The result of analysis using Moran's I Index states that spatial distribution pattern of medium industries is spread randomly. Factors affecting the preferences of medium-sized industrial sites to be close to the road or far from the road based on discriminant statistical analysis results are; (i) the distance between the source of raw materials and the industrial site; (ii) distance of workforce with industrial site; (iii) distance of industrial site with utility; (iv) market distance with industrial site; and (v) the distance of the industrial site to the owner's home. The most influential factor is the distance of industrial site with the house of the industry's owner and the distance of industrial site with utility because it has the biggest function coefficient value.
\end{abstract}

Keywords: location preferences, intermediate industries, geographic factors.

\section{PENDAHULUAN}

Lokasi merupakan salah satu faktor penting bagi kegiatan ekonomi termasuk kegiatan industri baik itu industri kecil, menengah, maupun besar. Untuk itu pada saat awal penentuan lokasi usaha sebuah kegiatan ekonomi harus mempertimbangkan faktor-faktor yang mempengaruhinya secara komprehensif. Pilihan lokasi untuk kegiatan ekonomi sangat beragam, namun untuk pelaku kegiatan ekonomi Industri
Kecil dan Menengah (IKM) biasanya memiliki keterbatasan dalam menentukan lokasi usahanya. Keterbatasan tersebut disebabkan karena modal, tempat dan lingkungan yang cocok, serta peraturan perundangan terkait.

Daldjoeni (1997) menyebutkan ada sejumlah faktor yang ikut menentukan berdirinya industri di suatu wilayah yaitu faktor ekonomis, historis, manusia, politis, dan akhirnya geografis (lokasi). Penelitian ini fokus pada faktor geografis yang menentukan berdirinya lokasi industri di 
suatu wilayah. Kemudian Robinson (1979) menjelaskan ada 6 (enam) hal yang termasuk dalam faktor geografis, yaitu: bahan mentah, sumberdaya tenaga (power resource), suplai tenaga kerja, suplai air, pasar; dan fasilitas transportasi.

Penentuan lokasi untuk pabrik/industri dapat dipengaruhi oleh faktor lokasi. Faktor lokasi ini banyak ragamnya, karena pertimbangan lokasi terkait dengan keseluruhan faktor dalam proses industri, yakni sejak masa pra produksi sampai distribusi produk. Banyaknya faktor menyebabkan beragam pula rumusan faktor yang dibuat oleh para ahli. Menurut Smith (1981) faktor-faktor lokasi industri adalah tanah, modal, bahan baku, tenaga kerja, pasar dan harga, transportasi, aglomerasi, dan organisasi, perilaku dan kesempatan. Harding dalam Sutanta (2010) menyebutkan bahwa faktor lokasi pabrik terdiri faktor lokasi makro dan faktor spesifik. Faktor lokasi makro yaitu jarak dari bahan baku, posisi terhadap lokasi pasar, tenaga kerja, akses transpotasi, iklim setempat, persetujuan pemerintah, subsidi investasi, dan biaya hidup. Faktor spesifik yaitu kemudahan tenaga kerja, sumber energi dan air, posisi fasilitas kota, pengaturan limbah, akses transportasi, peraturan daerah tentang lingkungan dan jalan, tanah dan iklim, lahan untuk perluasan dan jenis industri lain disekeliling. Kemudian Apple (1990) menyebutkan pertimbangan pemilihan daerah untuk lokasi pabrik adalah bahan baku, pasaran, transportasi, hukum negara, pajak, dan iklim.

Permasalahan lokasi muncul karena faktorfaktor yang mempengaruhinya tidak selalu terdapat pada satu lokasi yang sama dan seringkali tersebar/terpencar. Hal ini dapat terlihat pada kasus faktor-faktor penting yang dipertimbangkan dalam pemilihan lokasi masing-masing perusahaan berbeda. Pada suatu perusahaan faktor terpenting adalah dekat dengan pasar tetapi pada perusahaan lain yang lebih penting adalah dekat dengan sumber-sumber penyediaan bahan dan komponen. Beberapa perusahaan lainnya mungkin mempertimbangkan faktor lokasi dimana tersedia tenaga kerja yang mencukupi kebutuhan perusahaan, ataupun biaya transportasi yang sangat tinggi bila produk berat dan besar.

Kondisi tersebarnya faktor-faktor yang mempengaruhi lokasi industri menyebabkan ada industri yang berlokasi mendekati bahan baku, mendekati lokasi pasar, mendekati tenaga kerja maupun mendekati akses jalan sebagai jalur transportasi. Tersebarnya lokasi industri tersebut akan menyebabkan kesulitan bagi pemerintah daerah dalam mengembangkan kawasan industri yang lokasinya telah ditetapkan dalam Rencana
Tata Ruang Wilayah. Sehingga seringkali kawasan industri yang telah ditetapkan tersebut tidak terwujud.

Hal ini tentu berbeda apabila lokasi industri membentuk sebuah klaster maupun kawasan industri seperti yang diamanatkan dalam Peraturan Pemerintah No. 142 Tahun 2015 tentang Kawasan Industri. Peraturan tersebut mengamantkan bahwa setiap perusahaan industri wajib berlokasi di kawasan industri kecuali industri tersebut tidak menimbulkan pencemaran lingkungan hidup dan memerlukan bahan baku khusus (lokasi khusus untuk produksinya). Namun, tetap harus sesuai dengan Rencana Tata Ruang Wilayah.

Kabupaten Malang merupakan salah satu kabupaten yang ada di Provinsi Jawa Timur yang memiliki struktur ekonomi dominan yaitu pada kelompok sekunder dengan sumbangan sektor tersebut terhadap PDRB total Atas Dasar Harga Berlaku (ADHB) sekitar 42,79 persen. Sumbangan besar dari kelompok kategori sekunder tersebut dimotori oleh kategori industri pengolahan sebesar 29,98 persen. Hal ini tentu menggambarkan Kabupaten Malang memiliki potensi besar pada sektor industri pengolahan. Jumlah perusahaan industri pengolahan yang ada di Kabupaten Malang pada tahun 2015 tercatat terdapat 171 perusahaan industri pengolahan dengan komposisi subsektornya didominasi oleh industri makanan dan minuman sekitar 38,60 persen (66 unit usaha).

Adanya industri menengah di Kabupaten Malang mampu menyerap tenaga kerja sekitar 36.114 orang. Jika dilihat komposisi penyerapan tenaga kerja menurut subsektornya maka sekitar 56,97 persen diserap oleh subsektor industri pengolahan makanan, minuman dan tembakau, 16,27 persen oleh industri kimia dan barangbarang dari bahan kimia, minyak bumi, batu bara, karet dan barang-barang dari plastik dan sisanya oleh subsektor lainnya. Dengan gambaran kondisi Kabupaten Malang seperti disebutkan di atas maka menarik untuk diteliti mengenai industri menengah yang ada di Kabupaten Malang terkait preferensi lokasi industri tersebut dan faktor apa yang mempengaruhi preferensi lokasi tersebut.

Berdasarkan latar belakang tersebut maka perlu dilakukan penelitian mengenai preferensi lokasi industri menegah dan faktor apa yang mempengaruhi preferensi lokasi tersebut. Pada penelitian ini preferensi lokasi industri menengah dibedakan antara lokasi industri menengah yang berada dekat dengan jalan dan industri menengah yang lokasinya jauh dari jalan. Selain itu perlu juga melihat distribusi spasial dari lokasi industri menengah yang ada di Kabupaten Malang. 


\section{METODE PENELITIAN}

Penelitian ini adalah penelitian deduktif dengan metode analisa secara kuantitatif. Penelitian kuantitatif bertujuan untuk menjelaskan, meringkaskan berbagai kondisi, berbagai situasi, atau berbagai variabel yang timbul di masyarakat untuk menjadi objek penelitian itu berdasarkan apa yang terjadi. Kemudian mengangkat kepermukaan karakter atau gambaran tentang kondisi situasi antar variabel tersebut (Bungin, 2005). Analisa secara kuantitatif digunakan untuk menguji pengaruh variabel-variabel bebas (independen) terhadap variabel terpengaruh (dependen). Data yang digunakan adalah data primer yang diperoleh dari hasil survei dan wawancara dengan pelaku industri menengah serta data sekunder dari instansi pemerintah terkait data industri menengah yang ada di Kabupaten Malang.

Variabel dalam penelitian terdiri dari 2 (dua) variabel yaitu: (i) Variabel terikat (dependen) yaitu preferensi lokasi industri menengah mendekati jalan atau jauh dari jalan; (ii) Variabel bebas (independen) dalam penelitian berjumlah 5 (lima) variabel yaitu: bahan baku, tenaga kerja, pasar, transportasi, dan ketersediaan utilitas (air, listrik, internet) dengan variabel operasional sebagai berikut (Tabel 1).

\begin{tabular}{cll} 
Tabel 1. Variabel Penelitian \\
\hline No. & \multicolumn{1}{c}{ Variabel } & \multicolumn{1}{c}{ Sub Variabel } \\
\hline 1. & Bahan Baku & $\begin{array}{l}\text { Jarak antara sumber bahan baku } \\
\text { dengan lokasi industri }\end{array}$ \\
\hline 2. & Tenaga kerja & \begin{tabular}{l} 
Upah tenaga kerja \\
\cline { 3 - 3 }
\end{tabular} \\
& & $\begin{array}{l}\text { Jarak asal tenaga kerja dengan } \\
\text { lokasi industri }\end{array}$ \\
\cline { 3 - 3 } & & $\begin{array}{l}\text { Jarak lokasi industri dengan } \\
\text { rumah pemilik industri }\end{array}$ \\
\hline 3. & Transportasi & $\begin{array}{l}\text { Biaya transportasi pengangkutan } \\
\text { bahan baku }\end{array}$ \\
\cline { 3 - 3 } & & $\begin{array}{l}\text { Biaya transportasi pengangkutan } \\
\text { produk }\end{array}$ \\
\hline 4. & Utilitas & $\begin{array}{l}\text { Jarak lokasi industri dengan } \\
\text { sumber air, listrik, internet }\end{array}$ \\
\hline 5. & Pasar & Jarak pasar dari lokasi industri \\
\hline
\end{tabular}

Penelitian ini menggunakan data sampel yang diambil dari populasi. Populasi adalah seluruh data yang menjadi sampel penelitian (Sugiyono, 2005). Data yang digunakan untuk menentukan jumlah populasi adalah data Direktori Perusahaan Industri Besar dan Sedang yang ada di Provinsi Jawa Timur tahun 2016 dari Badan Pusat Statistik dan data usaha mikro, kecil dan menengah dari Dinas Koperasi dan Usaha Mikro Kabupaten Malang. Jumlah populasi industri menengah berdasarkan kedua data tersebut diketahui sebanyak 162 unit usaha yang sifatnya formal atau terdaftar.

Setelah diketahui jumlah populasi industri menengah di Kabupaten Malang mencapai 162 unit usaha maka dengan menggunakan rumus berikut.

$$
\mathrm{n}=\frac{\mathrm{N}}{\mathrm{Nd}^{2}+1}=\frac{162}{162\left(0,05^{2}\right)+1}=115
$$

keterangan:

$\mathrm{N}=$ jumlah populasi

$\mathrm{n}=$ jumlah sampel

$\mathrm{d}=\operatorname{presisi}(\alpha)=95 \%$

Namun, karena prinsipnya semakin banyak sampel semakin baik maka jumlah sampel dibulatkan menjadi 120 unit usaha. Dengan melihat karakteristik populasi yang ada maka pengambilan sampel menggunakan proportional (random) sampling yaitu teknik pengambilan sampel dengan cara simple random sampling, kemudian diproporsikan sesuai dengan jumlah sub-populasinya. Klasifikasi yang digunakan dalam penentuan sub populasi adalah berdasarkan Klasifikasi Baku Lapangan Usaha Indonesia (KBLI) tahun 2015. Adapun tahapan dalam menyeleksi tiap sampel dari masing-masing subpopulasi adalah secara sistematik. Berikut jumlah sampel dari masing-masing klasifikasi industri menengah yang ada dapat dilihat pada tabel berikut (Tabel 2).

Tabel 2. Jumlah Sampel Penelitian

\begin{tabular}{|c|c|c|}
\hline Sub Populasi & $\begin{array}{c}\text { Jumlah } \\
\text { Populasi } \\
\text { (Unit usaha) }\end{array}$ & $\begin{array}{c}\text { Jumlah } \\
\text { Sampel } \\
\text { (Unit usaha) }\end{array}$ \\
\hline Industri Makanan & 36 & 27 \\
\hline Industri Minuman & 3 & 2 \\
\hline Industri Pengolahan Tembakau & 18 & 13 \\
\hline Industri Tekstil & 7 & 5 \\
\hline Industri Pakaian Jadi & 6 & 4 \\
\hline $\begin{array}{l}\text { Industri Kulit, Barang dari } \\
\text { Kulit dan Alas Kaki }\end{array}$ & 4 & 3 \\
\hline $\begin{array}{l}\text { Industri Kayu, Barang Dari } \\
\text { Kayu, Gabus dan Barang } \\
\text { Anyaman dari Bambu, Rotan } \\
\text { dan Sejenisnya }\end{array}$ & 11 & 8 \\
\hline $\begin{array}{l}\text { Industri Kertas dan Barang dari } \\
\text { Kertas }\end{array}$ & 5 & 4 \\
\hline $\begin{array}{l}\text { Industri Percetakan dan } \\
\text { Reproduksi Media Rekaman }\end{array}$ & 3 & 2 \\
\hline $\begin{array}{l}\text { Industri Bahan Kimia dan } \\
\text { Barang dari Bahan Kimia }\end{array}$ & 6 & 4 \\
\hline $\begin{array}{l}\text { Industri Karet, Barang dari } \\
\text { Karet dan Plastik }\end{array}$ & 12 & 9 \\
\hline $\begin{array}{l}\text { Industri Barang Galian Bukan } \\
\text { Logam }\end{array}$ & 17 & 13 \\
\hline $\begin{array}{l}\text { Industri Barang Logam, Bukan } \\
\text { Mesin dan Peralatanya }\end{array}$ & 5 & 4 \\
\hline $\begin{array}{l}\text { Industri Mesin dan } \\
\text { Perlengkapan Ytdl }\end{array}$ & 1 & 1 \\
\hline $\begin{array}{l}\text { Industri Kendaraan Bermotor, } \\
\text { Trailler, dan Semi Trailler }\end{array}$ & 9 & 7 \\
\hline Industri Alat Angkut Lainnya & 4 & 3 \\
\hline Industri Furniture & 6 & 4 \\
\hline Industri Pengolahan Lainnya & 9 & 7 \\
\hline TO T A L & 162 & 120 \\
\hline
\end{tabular}

Metode analisis data yang digunakan adalah analisis pola distribusi spasial lokasi industri 
menengah dilakukan dengan menggunakan perhitungan Indeks Moran's (I) dengan rumus:

$$
I=\frac{n \sum_{i=1}^{n} \sum_{j=1}^{n} w i j(y i-\overline{\mathrm{y}})(y j-\overline{\mathrm{y}})}{\left(\sum_{i=1}^{n}(\mathrm{yi}-\overline{\mathrm{y}})^{2}\right)\left(\sum_{i=1}^{n} \sum_{j=1}^{n} w i j\right)}
$$

dimana yi merupakan nilai pengamatan lokasi industri menengah ke-i dengan rata-rata $\bar{y}$, dan $n$ adalah jumlah lokasi industri menengah. Adapun $\mathrm{w} * \mathrm{ij}$ adalah elemen pada matriks pembobot tak terstandardisasi antara daerah $\mathrm{i}$ dan $\mathrm{j}$ berukuran $\mathrm{n}$ $\mathrm{x} n$, yang dirumuskan dengan:

$$
\mathrm{w}^{*} \mathrm{ij}=(\mathrm{dij})-1
$$

dimana wij adalah bobot antara unit observasi kei dan ke-j dan dij adalah jarak euclidian antara centroid observasi ke-i dan ke-j. Rentang nilai Moran's I berada pada $-1<$ I $<1$. Pengambilan keputusan dalam identifikasi pola menggunakan kriteria nilai indeks I adalah apabila nilai I > Io maka mempunyai pola mengelompok (cluster), apabila I = Io maka memiliki pola menyebar tidak merata (tidak ada autokorelasi), dan apabila I < Io maka memiliki pola menyebar. Io merupakan nilai ekspektasi dari I yang dirumuskan $\mathrm{E}(\mathrm{I})=\mathrm{Io}=$ $-\frac{1}{(n-1)}$.

Analisis lain yang digunakan adalah analisis diskriminan. yaitu analisis untuk melihat hubungan dependensi (hubungan antar variabel) yang sudah dapat dibedakan antara variabel respon dan variabel penjelas. Lebih spesifik lagi, analisis diskriminan digunakan pada kasus variabel respon berupa data kualitatif dan variabel penjelas berupa data kuantitatif. Rumus fungsi yang digunakan untuk menghitung nilai diskriminan adalah dengan persamaan berikut.

$$
\mathrm{Di}=\mathrm{a}+\beta_{1} \mathrm{x}_{1}+\beta_{2} \mathrm{x}_{2}+\ldots .+\beta_{\mathrm{n}} \mathrm{x}_{\mathrm{n}}
$$

\section{Keterangan:}

$\begin{array}{lll}\mathrm{Di} & = & \text { nilai diskriminan } \\ \mathrm{a} & = & \text { konstanta } \\ \beta_{1} \ldots \beta_{\mathrm{n}} & = & \text { koefisien } \\ \mathrm{x}_{1} \ldots \mathrm{x}_{\mathrm{n}} & = & \text { variabel bebas }\end{array}$

setelah menghitung nilai diskriminan dari kasus/sampel kemudian menentukan titik batas (cut off) untuk mengelompokkan kasus/sampel termasuk kedalam kelompok preferensi lokasi industri menengah yang dekat dengan jalan atau jauh dari jalan. Rumus menentukan titik batas (cut off) yaitu:

$$
Z c u=\frac{N a Z b+N b Z a}{N a+N b}
$$

$\mathrm{Zcu}=$ nilai kritis sebagai cut off score

$\mathrm{Na}=$ jumlah sampel di grup a (dekat jalan)

$\mathrm{Nb}=$ jumlah sampel di grup $\mathrm{b}$ (jauh dari jalan)

$\mathrm{Za}=$ angka centroid pada grup a (dekat jalan)

$\mathrm{Zb}=$ angka centroid pada grup $\mathrm{b}$ (jauh dari jalan)

Sebelum melakukan analisis diskriminan terlebih dahulu dipilih variabel respon dan variabel penjelasnya. Variabel respon dalam analisis ini terdiri dari dua kelompok yaitu lokasi industri menengah yang dekat dengan jalan arteri dan lokasi industri menengah yang jauh dengan jalan arteri. Lokasi industri menengah dikelompokkan kedalam dekat dengan jalan apabila jaraknya kurang dari 500 meter dari jalan arteri dan jalan kolektor namun apabila diluar jarak tersebut dikelompokkan ke dalam lokasi jauh dari jalan. Gambaran secara spasial pengelompokkan lokasi industri tersebut dapat dilihat pada Gambar 1.

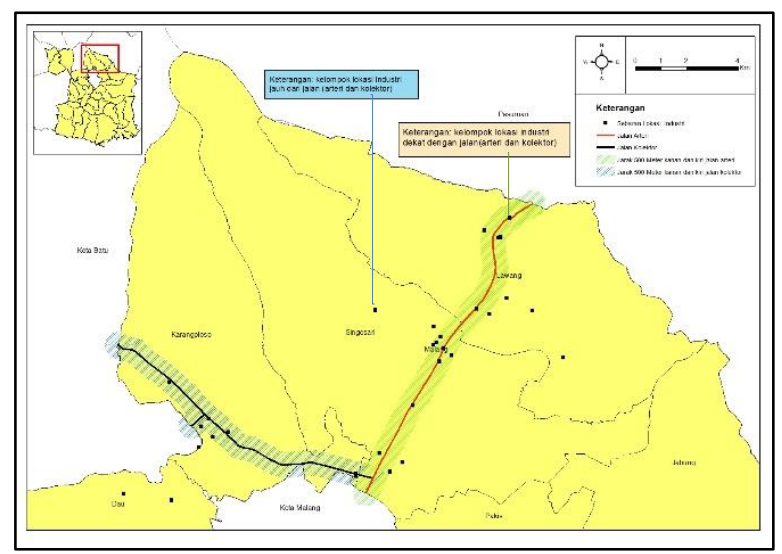

Gambar 1. Pengelompokkan Lokasi Industri Dekat atau Jauh dari Jalan

Kemudian untuk variabel penjelas yang digunakan dalam penelitian ini adalah: (i) jarak antara sumber bahan baku dengan lokasi industri; (ii) jarak asal tenaga kerja dengan lokasi industri; (iii) upah tenaga kerja; (iv) biaya pengangkutan bahan baku; (v) biaya pengangkutan hasil produksi industri; (vi) jarak pasar dari lokasi industri; (vii) jarak sumber utilitas dengan lokasi industri; dan (viii) jarak lokasi industri dengan rumah pemilik industri. Variabel penjelas tersebut didapat berdasarkan jawaban responden dan untuk variabel penjelas yang sifatnya geografis dihitung jaraknya dengan lokasi industri menengah dengan menggunakan bantuan google earth. Gambaran secara spasial variabel penjelas tersebut dapat dilihat pada Gambar 2.

Keterangan: 


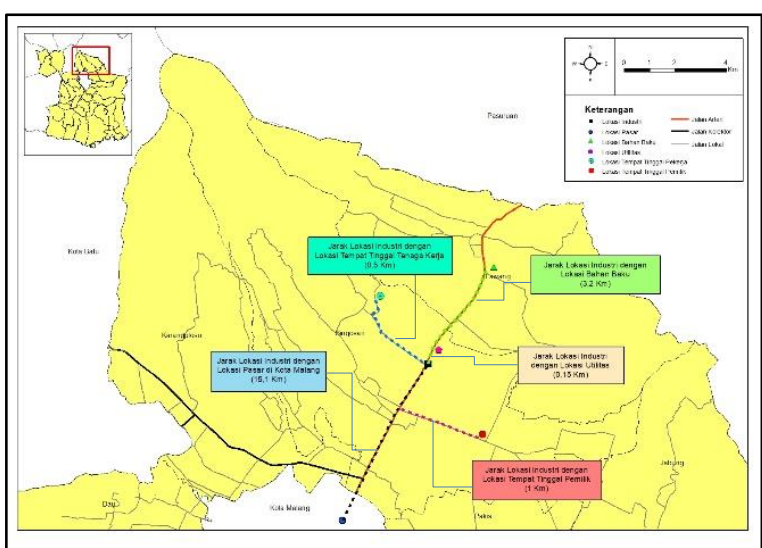

Gambar 2. Jarak Lokasi Industri dengan Faktor Geografis (Variabel Penjelas)

Hipotesis merupakan dugaan-dugaan sementara yang dapat diuji atau dikonfirmasi kebenarannya. Kerlinger (1973) mendefinisikan hipotesis sebagai pernyataan yang bersifat dugaan mengenai hubungan antara dua atau lebih fenomena atau variabel. Berikut adalah hipotesis yang dikemukakan dalam penelitian ini.

1. Tidak terdapat autokorelasi spasial pada lokasi industri menengah di Kabupaten Malang dengan persamaan hipotesis sebagai berikut.

$\mathrm{H}_{0}=$ tidak terdapat autokorelasi spasial ( $\mathrm{I}=$ 0 )

Kemudian bentuk hipotesis alternatifnya $\left(\mathrm{H}_{1}\right)$ ada dua yaitu:

$\mathrm{H}_{1}=$ terdapat autokorelasi spasial positif (I $>0$ )

$\mathrm{H}_{1}=$ terdapat autokorelasi spasial negatif (I $<0)$

2. Dalam menganalisis faktor geografis yang mempengaruhi preferensi lokasi industri menengah, sebagai hipotesis adalah terdapat perbedaan preferensi lokasi industri menengah yang berlokasi dekat dengan jalan arteri dan yang jauh dari jalan arteri. Bila dirumuskan dalam persamaan adalah sebagai berikut.

$\mathrm{H}_{0}$ : Tidak ada perbedaan yang signifikan (nyata) rata-rata semua variabel dalam semua grup.

$\mathrm{H}_{1}$ : Rata-rata semua variabel dalam semua grup adalah berbeda.

\section{HASIL DAN PEMBAHASAN}

Pengolahan dan analisa data dilakukan dengan menggunakan Indeks Moran $I$ untuk menganalisa pola sebaran industri menengah (autokorelasi spasial) dan metode statistik diskriminan untuk menjelaskan preferensi lokasi industri menengah beserta faktor-faktor yang mempengaruhinya.

\section{Analisis Autokorelasi Spasial}

Analisis pola distribusi spasial lokasi industri menengah dengan menggunakan perhitungan Indeks Moran's (I) dilakukan dengan bantuan software GIS yaitu ArcGIS 10.2 ekstensi Spatial Statistics dengan hasil sebagai berikut.

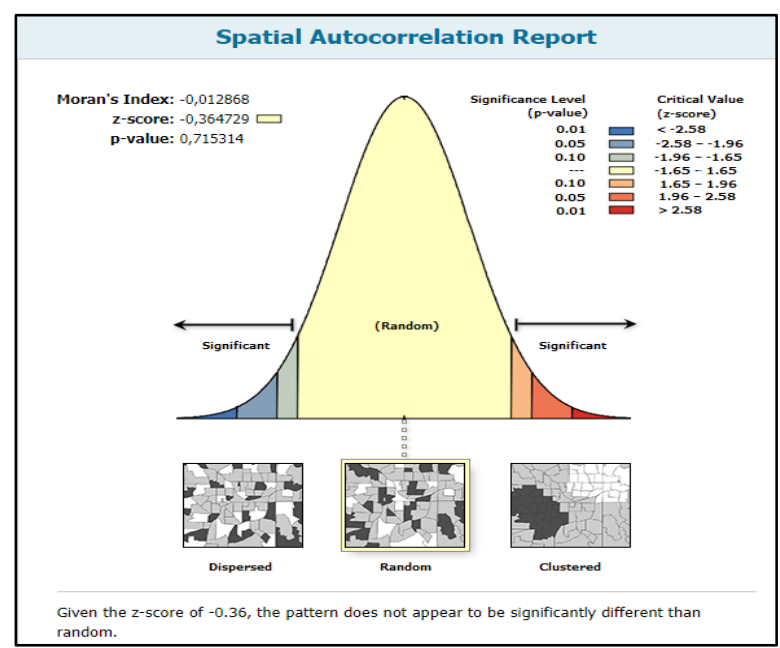

Gambar 3. Kurva hasil perhitungan indeks moran's (I)

\begin{tabular}{|r|r|}
\hline Global Moran's I Summary \\
\hline Moran's Index: & $-0,012868$ \\
\hline Expected Index: & $-0,009009$ \\
\hline Variance: & 0,000112 \\
\hline z-score: & $-0,364729$ \\
\hline p-value: & 0,715314 \\
\hline
\end{tabular}

Gambar 4. Tabel hasil perhitungan indeks moran's (I)

Berdasarkan kurva hasil perhitungan Indeks Moran's (I) pada (Gambar 3) maka dapat dikerahui pola lokasi industri menengah di Kabupaten Malang termasuk menyebar secara acak (random). Pola acak (random) ini bila dilihat berdasarkan karakteristik dari autokorelasi spasial menurut Kosfeld (2008) menunjukkan tidak ada autokorelasi spasial.

Selain menggunakan kurva autokorelasi spasial, pengambilan keputusan dapat juga dengan melihat nilai Indeks Moran's (I). Pada (Gambar 4) di atas diketahui nilai Indeks Moran's (I) yaitu sebesar -0,012868 dengan menggunakan pendekatan Euclidean Distance. Nilai tersebut kemudian dibandingkan dengan nilai Expected Index (Io) sebesar -0,009009 sehingga diketahui bahwa nilai Indeks Moran's $(-0,012868)$ lebih kecil daripada Expected Index $(-0,009009)$ atau I $<$ Io. Dengan demikian dapat disimpulkan bahwa lokasi industri menengah di Kabupaten Malang memiliki pola menyebar.

Kemudian pengambilan keputusan untuk pengujian hipotesis adalah hipotesis $\left(\mathrm{H}_{0}\right)$ ditolak jika nilai $\mathrm{Z}$ (hitung) $>\mathrm{Z}$ (tabel). Pada tabel hasil perhitungan uji indeks Moran's I diketahui nilai Z hitung sebesar $-0,364729$ dan nilai $Z$ tabel $(\alpha=$ 
$0,05)$ diketahui sebesar 1,645. Dengan demikian Z hitung $(-0,364729)<Z$ tabel $(1,645)$ sehingga dapat disimpulkan bahwa hipotesis (H0) diterima atau tidak terdapat autokorelasi spasial pada lokasi industri menengah di Kabupaten Malang.

Lokasi industri menengah yang tersebar secara acak pada jaringan jalan baik itu jalan arteri, kolektor, maupun jalan lokal dapat dilihat pada peta berikut (Gambar 5).

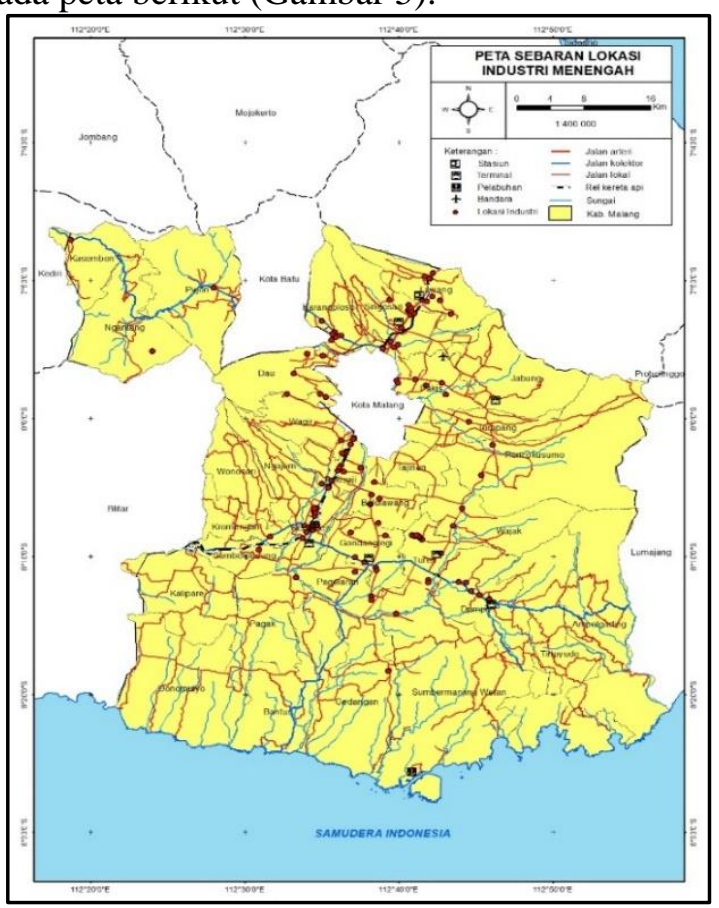

Gambar 5. Peta Sebaran Lokasi Industri Menengah.

\section{Analisis Diskriminan}

Kemudian analisis yang digunakan untuk mengukur faktor-faktor geografis yang mempengaruhi preferensi lokasi industri menengah dekat dengan jalan arteri atau jauh dari jalan arteri di Kabupaten Malang adalah analisis diskriminan. Proses analisis diskriminan dilakukan dengan menggunakan program SPSS 24.0 dengan memasukkan semua data responden kedalam proses analisis. Sebelum dilakukan analisis diskriminan dilakukan uji normalitas data dan didapatkan sejumlah 10 data responden yang outlier sehingga tidak diikutkan dalam analisis diskriminan.

Langkah awal dalam melakukan analisis terhadap hasil statistik diskriminan adalah dengan menguji asumsi sama tidaknya matriks kovarian dari semua variabel bebas dalam setiap kelompok (group covariance matrices). Apabila asumsi tersebut tidak terpenuhi maka akan menyebabkan fungsi atau model yang diperoleh menunjukkan hubungan yang kurang tepat antara variabel bebas dengan variabel terikat. Hal tersebut dapat diketahui dengan melihat tabel Log Determinant (Tabel 2).
Tabel 2. Hasil Perhitungan Log Determinants Pada Analisis Diskriminan

\begin{tabular}{|c|c|c|}
\hline \multicolumn{3}{|c|}{ Log Determinants } \\
\hline $\begin{array}{l}\text { Lokasi industri dekat jalan } \\
\text { atau tidak }\end{array}$ & Rank & Log Determinant \\
\hline Dekat & 8 & 67,907 \\
\hline Jauh & 8 & 65,613 \\
\hline Pooled within-groups & 8 & 67,177 \\
\hline $\begin{array}{l}\text { The ranks and natural logari } \\
\text { those of the group covariance }\end{array}$ & $\begin{array}{l}\text { determina } \\
\text { ces. }\end{array}$ & printed are \\
\hline
\end{tabular}

Hasil analisis diskriminan pada tabel di atas diketahui bahwa nilai Log Determinant untuk grup lokasi industri menengah dekat dengan jalan adalah 67,907 dan untuk grup lokasi industri menengah jauh dari jalan sebesar 65,613. Apabila dilihat kedua angka tersebut maka nilainya berbeda sedikit sehingga dapat disimpulkan bahwa group covariance matrices sama atau tidak memiliki perbedaan yang jelas.

Analisis selanjutnya adalah melihat uji kesamaan varians (variance homogenity test) sebagai syarat layak tidaknya kita menggunakan analisis diskriminan pada tabel Test Results (Tabel $3)$.

Tabel 3. Hasil Perhitungan Test Results Pada Analisis Diskriminan

\begin{tabular}{|llr|}
\hline \multirow{3}{*}{ Box's M } & \multicolumn{2}{|c|}{ Test Results } \\
\hline F & Approx. & 47,288 \\
\cline { 2 - 3 } & df1 & 1,210 \\
\cline { 2 - 3 } & df2 & 36 \\
\cline { 2 - 3 } & Sig. &, 181 \\
\hline \multicolumn{2}{|l}{$\begin{array}{l}\text { Tests null hypothesis of equal population } \\
\text { covariance matrices. }\end{array}$} \\
\hline
\end{tabular}

Analisis uji kesamaan varians (variance homogenity test) dapat dilakukan dengan melihat nilai Signifikansi pada tabel 3 yaitu sebesar 0,181 atau lebih besar daripada tingkat signifikansi untuk pengujian asumsi yaitu 0,05. Dengan demikian disimpulkan penyebaran varians sama (homogen) dan analisis diskriminan dapat dilanjutkan.

Setelah asumsi analisis diskriminan telah terpenuhi dan dapat dilanjutkan maka dapat dilihat keeratan hubungan antara discriminant score dengan grup (dekat atau jauh dari jalan arteri) pada tabel eigenvalues. Untuk analisis tabel eigenvalues dapat dilihat pada angka canonical correlation. Berikut tabel eigenvalues hasil pengolahan statistik (Tabel 4).

Tabel 4. Hasil Perhitungan Eigenvalues Pada Analisis Diskriminan

\begin{tabular}{|c|c|c|c|c|}
\hline \multicolumn{5}{|c|}{ Eigenvalues } \\
\hline Function & Eigenvalue & $\begin{array}{c}\% \text { of } \\
\text { Variance }\end{array}$ & $\begin{array}{c}\text { Cumulative } \\
\%\end{array}$ & $\begin{array}{l}\text { Canonical } \\
\text { Correlation } \\
\end{array}$ \\
\hline 1 &, $057 \mathrm{a}$ & 100,0 & 100,0 & ,233 \\
\hline
\end{tabular}


Berdasarkan tabel Eigenvalues di atas maka dapat diketahui angka canonical correlation sebesar 0,233 (23,3\%) jika dikuadratkan yang berarti 23,3 persen varians dari variabel preferensi lokasi industri menengah yang berlokasi dekat atau jauh dari jalan arteri dapat dijelaskan oleh variabel predictors yaitu jarak antara sumber bahan baku dengan lokasi industri, biaya pengangkutan bahan baku, jarak asal tenaga kerja dengan lokasi industri, upah tenaga kerja, jarak lokasi industri dengan utilitas (sumber air, listrik, internet), jarak pasar dengan lokasi industri, biaya pengangkutan hasil produksi industri, jarak lokasi industri dengan rumah pemilik industri.

Selanjutnya untuk menguji hipotesis yang telah dirumuskan dalam penelitian ini maka dapat dibandingkan angka Chi-square hasil perhitungan pada tabel Wilks' Lambda dengan angka Chisquare pada tabel. Berikut hasil perhitungan Wilks' Lambda (Tabel 5).

Tabel 5. Output Hasil Perhitungan Wilks' Lambda Pada Analisis Diskriminan

\begin{tabular}{|lr|r|r|r|}
\hline \multicolumn{5}{|c|}{ Wilks' Lambda } \\
Test of & \multicolumn{1}{c|}{ Wilks' } & & \\
Function (s) & Lambda & Chi-square & df & \multicolumn{1}{c|}{ Sig. } \\
\hline 1 &, 946 & 5,783 & 8 &, 671 \\
\hline
\end{tabular}

Angka Chi-square hasil perhitungan analisis diskriminan pada tabel di atas sebesar 5,783 apabila dibandingkan dengan angka Chisquare tabel dengan melihat tabel Chi-square (n$1 ; 0,05)$ diperoleh nilai sebesar 14,07 maka dapat diketahui nilai Chi-square hitung $(5,783)<C h i$ square tabel $(14,07)$. Ini menunjukkan tidak adanya perbedaan yang signifikan antargrup pada model diskriminan (preferensi lokasi industri menengah dekat atau jauh dengan jalan arteri cenderung sama). Pada nilai signifikansi diketahui nilai 0,671 atau lebih besar dari 0,05 . Dengan demikian hipotesis $\left(\mathrm{H}_{0}\right)$ dalam penelitian ini diterima atau tidak adanya perbedaan yang signifikan antargrup (preferensi lokasi industri menengah yang dekat dengan jalan arteri sama dengan preferensi lokasi industri menengah yang jauh dari jalan arteri).

Kemudian untuk persamaan diskriminan yang terbentuk dapat dilihat pada tabel Canonical Discriminant Function Coefficient berikut (Tabel $6)$.
Tabel 6. Output Hasil Perhitungan Discriminant Function Coefficient Pada Analisis Diskriminan

\begin{tabular}{|c|c|}
\hline \multicolumn{2}{|c|}{$\begin{array}{l}\text { Canonical Discriminant Function } \\
\text { Coefficients }\end{array}$} \\
\hline & $\begin{array}{c}\text { Function } \\
1\end{array}$ \\
\hline Jarak bahan baku ke tempat lokasi industri & 013 \\
\hline Biaya transportasi bahan baku & 000 \\
\hline Jarak rumah pekerja ke tempat usaha &,- 064 \\
\hline Gaji pekerja & 000 \\
\hline Jarak pemasaran produk $(\mathrm{km})$ &,- 008 \\
\hline Biaya transportasi pemasaran produk & 000 \\
\hline Jarak utilitas ke lokasi industri $(\mathrm{km})$ &, 328 \\
\hline Jarak rumah pemilik industri $(\mathrm{km})$ & 7,723 \\
\hline (Constant) & .522 \\
\hline Unstandardized coefficients & \\
\hline
\end{tabular}

Berdasarkan tabel di atas maka dapat disusun persamaan diskriminan berikut.

Di $=\mathbf{0 , 5 2 2}+\mathbf{0 , 1 3}($ Jarak antara sumber bahan baku dengan lokasi industri - $\mathbf{0 , 6 4}$

(Jarak asal tenaga kerja dengan lokasi industri) + 0,328 (Jarak lokasi industri dengan utilitas) - $\mathbf{0 , 0 8}$ (Jarak pasar dengan lokasi industri) $+\mathbf{7 , 7 2 3}$ (Jarak lokasi industri dengan rumah pemilik industri).

Dari persamaan tersebut terlihat bahwa jarak lokasi industri dengan rumah pemilik industri adalah yang paling dominan dalam memprediksi perbedaan kelompok karena nilai koefisiennya tertinggi dan berikutnya adalah variabel jarak utilitas dengan lokasi industri.

Untuk mengukur derajat keberhasilan klasifikasi sampel pada grup atau kelompok, dengan menghitung seberapa banyak obyek (lokasi) didalam masing-masing kelompok yang diklasifikasikan secara benar, dan seberapa banyak yang salah dalam klasifikasi maka dapat dilihat pada tabel Classification Results berikut (Tabel 7).

Tabel 7. Output Hasil Perhitungan Classification Results Pada Analisis Diskriminan

\begin{tabular}{|c|c|c|c|c|c|}
\hline \multicolumn{6}{|c|}{ Classification Results ${ }^{\mathrm{a}}$} \\
\hline & & \multirow{2}{*}{$\begin{array}{l}\text { Lokasi industri } \\
\text { dekat jalan atau } \\
\text { tidak }\end{array}$} & \multicolumn{2}{|c|}{$\begin{array}{l}\text { Predicted Group } \\
\text { Membership }\end{array}$} & \multirow[b]{2}{*}{ Total } \\
\hline & & & Dekat & Jauh & \\
\hline \multirow[t]{4}{*}{ Original } & \multirow[t]{2}{*}{ Count } & Dekat & 28 & 26 & 54 \\
\hline & & Jauh & 18 & 38 & 56 \\
\hline & \multirow[t]{2}{*}{$\%$} & Dekat & 51,9 & 48,1 & 100,0 \\
\hline & & Jauh & 32,1 & 67,9 & 100,0 \\
\hline
\end{tabular}

Secara keseluruhan ketepatan klasifikasi dari model diatas adalah 60\%. Angka ini menunjukkan model diatas cukup dapat digunakan untuk analisis diskriminan. Hal ini diperkuat dengan uji t yang membandingkan nilai $\mathrm{t}$ hitung dengan nilai $\mathrm{t}$ tabel. Nilai t hitung didapat melalui rumus: 


$$
\mathrm{t}=\frac{\mathrm{p}-0,5}{\sqrt{\frac{0,5 \times(1-0,5)}{N}}}
$$

Keterangan:

$$
\begin{aligned}
& \mathrm{p}=\begin{array}{l}
\text { proporsi sampel yang diklasifikasikan } \\
\text { dengan benar }(60 \%=0,6)
\end{array} \\
& \mathrm{N}=\text { jumlah sampel }
\end{aligned}
$$

$$
\begin{aligned}
\mathrm{t} & =\frac{\mathrm{p}-0,5}{\sqrt{\frac{0,5 \times(1-0,5)}{N}}} \\
& =\frac{0,6-0,5}{\sqrt{\frac{(0,5 \times(1-0,5))}{110}}}=45,45
\end{aligned}
$$

Dengan nilai $\mathrm{t}$ hitung sebesar 45,45 dan dibandingkan dengan nilai t tabel sebesar 1,659 maka diketahui nilai $t$ hitung $(45,45)>$ nilai $t$ tabel $(1,659)$ sehingga variabel independen yang dimasukkan dalam model analisis secara individual mempengaruhi variabel dependen.

Pada Tabel 7 dapat diketahui bahwa dari 110 lokasi yang diklasifikasikan, 28 lokasi diklasifikasikan dengan benar kedalam grup dekat dengan jalan $(25,45 \%)$ dan 38 lokasi diklasifikasikan benar kedalam grup jauh dari jalan (34,54 \%), dan 44 lokasi mengalami misclassified (salah klasifikasi). Berdasarkan hasil tersebut terlihat bahwa pengklasifikasian terbaik adalah untuk pengelompokkan lokasi yang jauh dengan jalan arteri. Jumlah industri menengah yang pada awalnya dekat dengan jalan kemudian berpindah ke grup jauh dari jalan ada sebanyak 26 lokasi. Perubahan tersebut disebabkan karena jarak rumah pemilik industri dengan lokasinya industrinya sangat dekat atau lokasi industri menyatu dengan rumah pemiliknya. Selain itu disebabkan juga oleh jarak utilitas ke lokasi industri yang dekat bahkan beberapa industri menengah penggunaan utilitas untuk industri digunakan juga untuk rumah tangga. Kemudian jarak asal tenaga kerja juga cukup jauh. Sedangkan pada grup jauh dari jalan yang berpindah ke grup dekat dengan jalan ada sebanyak 18 lokasi. Perubahan klasifikasi terjadi karena jarak utilitas ke lokasi industri dan jarak utilitas ke lokasi industri yang dekat yang cukup jauh, dan jarak tempat tinggal pekerja ke lokasi industri yang dekat.

Pengelompokkan terhadap industri menengah di Kabupaten Malang berdasarkan angka skor kasus hasil perhitungan. Industri menengah yang memiliki angka skor kasus diatas nilai Cut off maka akan dikelompokkan ke dalam lokasi industri menengah dekat dengan jalan sedangkan industri menengah yang memiliki angka skor kasus dibawah nilai Cut off maka dikelompokkan ke dalam lokasi industri menengah yang jauh dari jalan. Penghitungan nilai Cut off dilakukan dengan menggunakan rumus berikut.

$$
\begin{aligned}
Z c u & =\frac{N a Z b+N b Z a}{N a+N b} \\
& =\frac{(54 \mathrm{x}-0,233)+(56 \times 0,241)}{54+56} \\
& =0,0083
\end{aligned}
$$

Nilai $Z a$ (angka centroid pada grup a (dekat jalan) dan $Z b$ (angka centroid pada grup b (jauh dari jalan) pada rumus tersebut di atas dihasilkan berdasarkan tabel Functions at Group Centroids (Tabel 8).

Tabel 8. Output Hasil Perhitungan Functions at Group Centroids Pada Analisis Diskriminan

\begin{tabular}{|lr|}
\hline \multicolumn{3}{|c|}{ Functions at Group Centroids } \\
\multicolumn{3}{|c|}{ Function } \\
Lokasi industri dekat jalan atau tidak & 1 \\
\hline Dekat &, 241 \\
\hline Jauh &,- 233 \\
\hline $\begin{array}{l}\text { Unstandardized canonical discriminant } \\
\text { evaluated at group means }\end{array}$ \\
\hline
\end{tabular}

\section{KESIMPULAN}

Pola lokasi industri menengah di Kabupaten Malang berdasarkan hasil perhitungan Indeks Moran's (I) termasuk pola menyebar secara acak (random). Pola acak (random) ini bila dilihat berdasarkan karakteristik dari autokorelasi spasial menurut Kosfeld (2008) menunjukkan tidak ada autokorelasi spasial. Lokasi industri menengah tersebut tersebar secara acak pada jaringan jalan baik itu jalan arteri, kolektor, maupun jalan lokal.

Faktor yang mempengaruhi preferensi lokasi industri menengah dekat dengan jalan atau jauh dari jalan adalah: (i) jarak antara sumber bahan baku dengan lokasi industri; (ii) jarak asal tenaga kerja dengan lokasi industri; (iii) jarak lokasi industri dengan utilitas; (iv) jarak pasar dengan lokasi industri; dan (v) jarak lokasi industri dengan rumah pemilik industri. Faktor yang paling berpengaruh adalah jarak lokasi industri dengan rumah pemilik industri dan jarak lokasi industri dengan utilitas karena memiliki nilai koefisien fungsi yang paling besar sesuai dengan persamaan diskriminan yang terbentuk yaitu:

Di $=\mathbf{0 , 5 2 2}+\mathbf{0 , 1 3}$ (Jarak antara sumber bahan baku dengan lokasi industri - $\mathbf{0 , 6 4}$ (Jarak asal tenaga kerja dengan lokasi industri) + $\mathbf{0 , 3 2 8}$ (Jarak lokasi industri dengan utilitas) - $\mathbf{0 , 0 8}$ (Jarak pasar dengan lokasi industri) + 7,723 (Jarak lokasi industri dengan rumah pemilik industri). 
Rekomendasi yang dihasilkan dari penelitian ini adalah dalam menentukan lokasi kawasan industri maupun kawasan peruntukan industri oleh Pemerintah Daerah perlu mempertimbangkan faktor-faktor yang tidak hanya bersifat faktor lokasi namun juga faktor internal terutama dari pelaku industri yang menentukan pilihan lokasi bagi industrinya seperti faktor kedekatan dengan tempat tinggal pemilik industri. Kemudian untuk penelitian mengenai pemilihan lokasi industri menengah sudah banyak dilakukan dengan temuan faktor-faktor yang mempengaruhinya sangat beragam. Faktor-faktor lokasi tersebut mulai dari yang sifatnya umum untuk wilayah makro maupun yang sifatnya khusus bagi wilayah dengan cakupan sempit. Namun, untuk faktor lokasi yang bersifat khusus/spesifik dan berlaku bagi wilayah mikro masih belum banyak faktor yang dikemukakan. Untuk itu pada penelitian-penelitian selanjutnya mengenai pemilihan lokasi industri dapat dilakukan penelitian mengenai faktor-faktor khusus tersebut yang disesuaikan dengan jenis industri yang menjadi fokus penelitiannya. Selain faktor lokasi yang bersifat khusus dapat juga dilengkapi dengan faktor-faktor yang sifatnya faktor non lokasi geografis sehingga dapat memperkaya faktor yang menjadi pertimbangan dalam pemilihan lokasi industri.

\section{DAFTAR PUSTAKA}

Apple, James M. 1990. Tata Letak Pabrik dan Pemindahan Bahan. Terjemahan Ir. Nurhayati, MT dan Mardiono, MSc. Bandung. Penerbit ITB.

Bungin, B. 2005. Metodologi Penelitian Kuantitatif. Jakarta. Kencana Prenada Media Group.

Daldjoeni, N. 1997. Geografi Baru: Organisasi Keruangan Dalam Teori dan Praktek. Bandung. Penerbit Alumni.

Klasifikasi Baku Lapangan Usaha Indonesia (KBLI) tahun 2015. Badan Pusat Statistik

Kosfeld, Reinhold. 2008. Spatial Econometrics. Institute of Economics. University of Kassel. $\quad$ https://www.unikassel.de/fb07/fileadmin/datas/fb07/5Institute/IVWL/Kosfeld/lehre/spatial/Spati alEconometrics4b.pdf, diakses pada 4 Mei 2018

Peraturan Pemerintah No. 142 Tahun 2015 tentang Kawasan Industri.

Robinson, H. 1979. Economic Geography. USA. Macdonald \& Evans Ltd.
Smith. D. M., 1981. Industrial Location. An Economic Geographical Analysis. Second Edition. New York. John wiley \& Sons, Inc. Sugiyono. 2005. Statistik Untuk Penelitian. Bandung. Alfabeta.

Sutanta. 2010. Faktor-Faktor Penyebab Tidak Berkembangnya Kawasan Industri Nguter Kabupaten Sukoharjo. Tesis Magister Teknik Pembangunan Wilayah dan Kota. Semarang. Universitas Diponegoro. 
